\title{
Between the two hearths: Site formation processes and spatial organization at the Upper Paleolithic open-air site of Kamihoronai-Moi, Hokkaido (Japan)
}

\author{
Yuichi Nakazawa*1, Masami Izuho*2, a and Fumito Akai*3
}

\begin{abstract}
Archaeologists studying prehistoric hunter-gatherer sites have long been interested in variability in spatial organization and intrasite activities. In order to make explicit inferences on intrasite human activities, we investigate into site formation processes of the late Upper Paleolithic open-air site of Kamihoronai-Moi (ca. 14,400-14, 800 yrs BP) in Hokkaido, northern Japan. First, in order to predict the chance of having palimpsest accumulations, we propose a formal model of site formation processes in terms of the relationship between human occupational intensity and depositional rate. An examination of the trampling effect on the vertical displacement of artifacts shows that artifacts were little dispersed from the past occupational surface. Since the result of vertical displacement allows us to perform intrasite spatial analysis, we performed a visual and a quantitative analysis of the spatial patterns of burnt artifacts around the two hearths (i.e., the evident and invisible hearths). These analyses demonstrate that a group of occupants likely utilized both hearths simultaneously, and their occupational intensity (i.e., duration of occupation and frequency of occupation) was low. Given the predictable model of palimpsest accumulations, the study site had a median degree of chance in having palimpsests. On the other hand, the results of our analysis suggest that the site was shortly occupied and presumably functioned as a transit camp. Moreover, classes of raw materials (i.e., obsidian, hard shale, and sandstones) were differentially consumed in and around the two hearths, implying that division of labor between the two hearth-centered areas was pronounced in the study site. The present study of the Kamihoronai-Moi will provide a rare but worthwhile example toward understanding behavioral variability in Upper Paleolithic hunter-gatherer microspace use organization in a short-term open-air site.
\end{abstract}

Keywords : hearths, intrasite activities, palimpsests, Upper Paleolithic, Hokkaido

\section{Introduction}

Archaeologists have always questioned how and why variability in the archaeological record was formed. One of the intellectual missions in studying archaeological record forma- tion is to make valid inferences about how human behavior was organized across site activity areas (e.g., Schiffer, 1976 ; Hietala, 1984 ; Kent, 1987 ; Gamble and Boismier, 1991 ; Kroll and Price, 1991). To study intrasite human activities, archaeologists use a site as an analytical

Received August 7, 2008. Accepted January 24, 2009.

*1 Department of Anthropology, MSC01-1040, Anthropology, University of New Mexico. Albuquerque, NM 871310001, USA.

*2 Sapporo Center for Cultural Heritage. Minami 22, Nishi 13, Chuo-ku, Sapporo, 064-0922, Japan (Present address : Faculty of Social Sciences and Humanities, Tokyo Metropolitan University. 1-1 Minami Osawa, Hachioji, Tokyo, 192-0397 Japan).

*3 Graduate School of Letters, Hokkaido University, Kita 7, Nishi 10, Chuo-ku, Sapporo, 060-0810, Japan.

*a Corresponding author : izuhom@tmu.ac.jp 
unit (e.g., Wandsnider, 1996; Audouze and Enloe, 1997 ; Vaquero and Pastó, 2001 ; Enloe, 2006). Each site has unique depositional processes that were affected by climatic factors at global and local scales. Various degrees of depositional rates are affected by a unique geology, geomorphology, and topography in and around a site, which also alters patterns of artifact distributions (Wood and Johnson, 1978 ; Waters, 1992). Given the effects of these various environmental factors on site spatial patterns, we need to assess the degree of site integrity to discuss how human activities were organized across a site. Moreover, studies of extant and prehistoric hunter-gatherers have demonstrated that human foragers repeatedly settled favorable locations to procure and process available resources around them, such as terrestrial fauna, marine resource, and fuel (e.g., Akazawa, 1980 ; Binford, 1980, 1982 ; Straus and Clark, 1986 ; Straus, 1987 ; Jochim, 1991 ; Huckell, 1996). Seasonally revisited locations result in the accumulations of debris from multiple occupational episodes. These "palimpsest accumulations" (Binford, 1980 : p. 9 ; see also Straus, 1979) have been ubiquitously recognized among various classes of archaeological sites (Bailey, 2007).

Despite the recognition of palimpsests and the variation in site integrity, archaeologists tend to employ an analytical unit that is derived from a single archaeological stratum or deposit, namely as an "assemblage" or "component" (Villa and Courtin, 1983 : p. 269-270). A defined analytical unit is then provided for building a chronology to discuss diachronic changes of human cultures (Binford and Sabloff, 1982 ; Lyman and O'Brien, 1999). The idea of cultural chronology is based on the premise that a stratum and artifacts yielded from a stratum are deposited approximately at the same time, represented by the notion of a "depositional event” (Lyman and O'Brien, 1999 : p. 58). A vertically discrete unit of stratum or deposit on which archaeologists have constructed synchronic and diachronic relations in units of the archaeological record (e.g., sites and artifacts), however, is arbitrarily defined, usually based on intermingled criteria such as sediment color, texture, matrix, and inclusions (Lyman and O’Brien, 1999 : p. 60 ; Stein, 2001). Given the prob- lem of stratum and deposit as a behaviorally meaningful unit as well as the palimpsest and varied depositional processes that operated to create the archaeological record, it is necessary to set a reliable analytical unit from an archaeological deposit to discuss human behavioral organization. To accomplish this broad goal of archaeological theory building, we investigate the spatial distribution of artifacts and hearths on the late Upper Paleolithic locality of the Kamihoronai-Moi site (ca. 14,40014,800 yrs BP), a deeply-buried open-air site in Hokkaido, Japan (Fig. 1). In order to furnish a research framework of site formation processes, we first present a formal model of palimpsest accumulations in terms of the relationship of human occupational intensity and depositional rate. Second, we examine site integrity through an examination of vertical displacement of artifacts. Based on the results of the spatial integrity analysis, we then discuss variability in intrasite human activities with respect to hearth use.

\section{A model of palimpsests}

Given the perceptions that palimpsests operated to create an archaeological record and depositional processes vary across site activity area and through time, we raise the research question as to how many human occupational episodes are overlapped in a site activity area. Here, we provide a model that predicts the occurrence of palimpsest accumulations, labeled as the "probability of palimpsests", considering depositional rate, group size (number of occupants), and human occupational intensity. The probability of palimpsests varies depending on the degree of depositional rate (Waters, 1992 : p. 96-97), number of site occupants, site occupational duration, and frequency of occupations. Combination with the latter two factors (i.e., site occupational duration, and frequency of occupations) is regarded as "occupational intensity". This relationship is mathematically formulated as shown below. The outcome of $P_{p}$ is dependent on the degree of $N, D, F$, and $d$, as illustrated in Figure 2.

$$
P_{p}=N^{*} D^{*} F / d
$$

$P_{p}$ is the probability of palimpsests, $N$ is the 


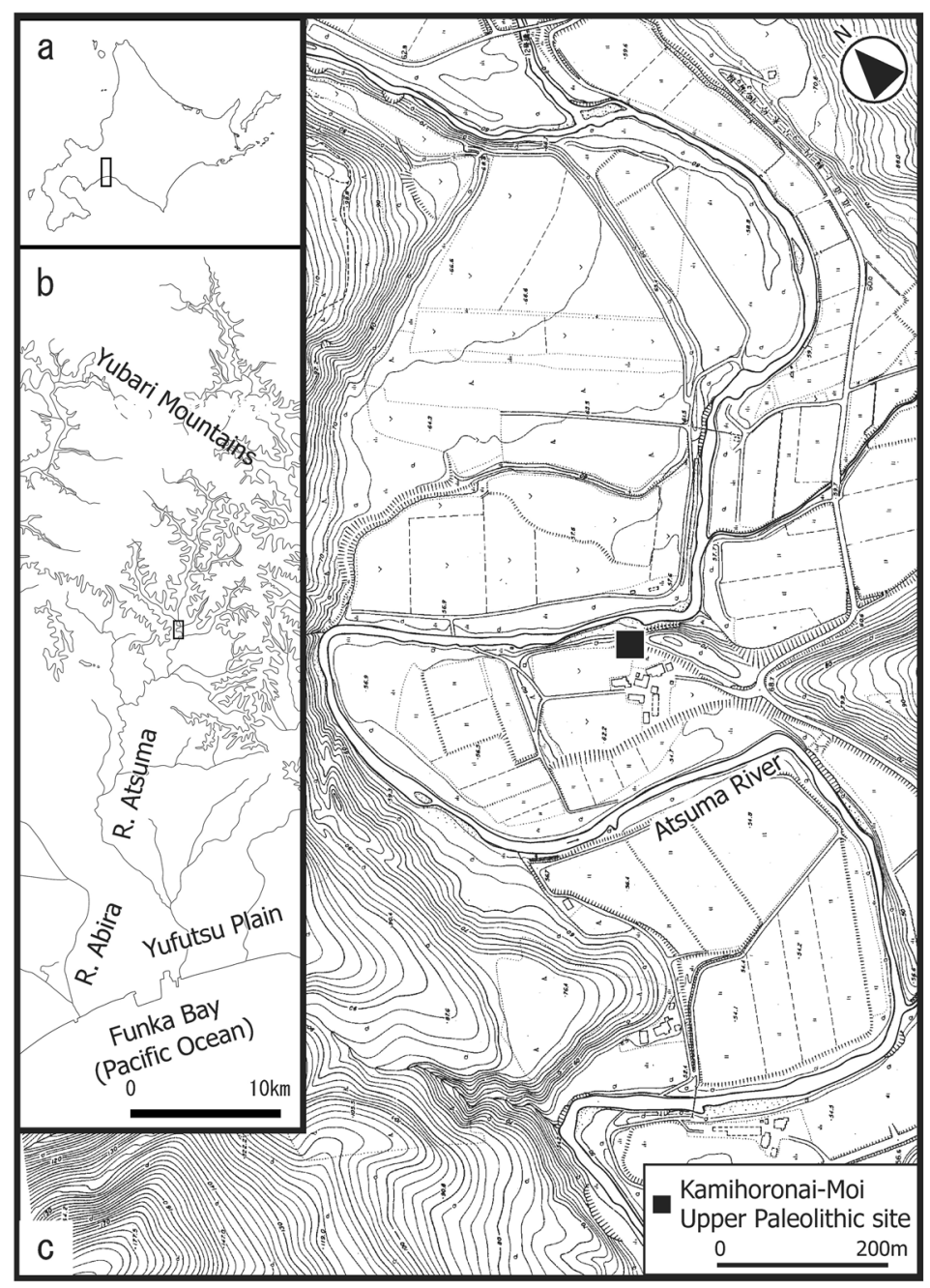

Fig. 1 Location of the Kamihoronai-Moi site in Hokkaido (a, b) and the surrounding topography (c)

Contour interval is $2 \mathrm{~m}$.

number of occupants, $D$ is the duration of occupation, $F$ designates the frequency of occupations, and $d$ is the depositional rate. If $d, N$, and $D$ are constant, $P_{p}$ varies directly with $F$. For example, when a foraging party of same size settles a particular site location annually, such as in every 3 years, $F$ (frequency of occupations) will become low. In contrast, if that particular location is occupied seasonally, such as once a year (e.g., every summer), $F$ will be high. On the other hand, when $d$ (depositional rate) is high such as on floodplain, $P_{p}$ (probability of palimpsests) will decrease, because the high rate of sedimentation will increase the chance of separating occupational episodes being preserved as individual events (Ferring, 1986 ; Waters, 1992).

\section{Site stratigraphy, lithic assemblage, and the two hearths in the Upper Pa- leolithic locality of the Kamihoronai- Moi site}

The Kamihoronai-Moi site is situated at the eastern edge of the southern Ishikari Lowland in central Hokkaido $\left(42^{\circ} 47^{\prime} 15^{\prime \prime} \mathrm{N}, 141^{\circ} 59^{\prime} 56^{\prime \prime} \mathrm{E}\right.$; 
$65.6 \mathrm{~m}$ above sea level). The site is on the left river bank of the Atsuma River (Fig. 1-c), which flows down the west slope of the Yubari Mountains and runs into the present Pacific coast about $30 \mathrm{~km}$ to the southwest. The local terrain

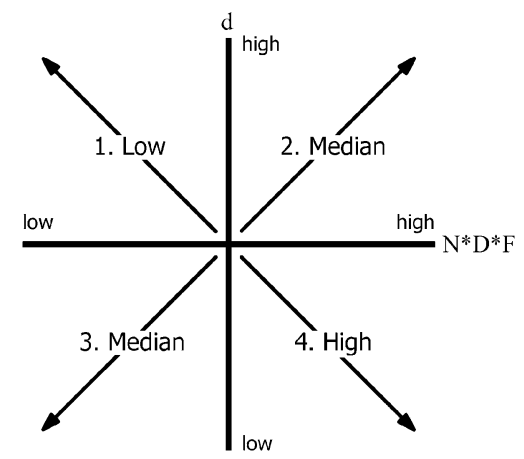

Fig. 2 Model of palimpsest accumulations, illustrating the probability of having palimpsest accumulations, which is depending on the depositional rate $(d)$, number of occupants $(N)$, duration of occupation $(D)$, and frequency of reoccupations $(F)$ Each quadrant represents relative degree in the probability of palimpsests. topography was divided into seven units consisting of the flood plain $\left(\mathrm{T}_{0}\right)$, five river terraces $\left(\mathrm{T}_{1}-\mathrm{T}_{5}\right)$ from lowest to highest, and a mountain/hill slope (H) (Atsuma Board of Education, 2006). The thickness of $T_{3}$, where the Upper Paleolithic occupation was identified, is approximately $350 \mathrm{~cm}$ thick and lying above the mudstone bedrock. It is divided into five lithostratigraphic units, $\mathrm{V}$ to IX from the bottom to top (Fig. 3). Unit V (100 cm in thickness) consists of gravels that were deposited along the ancient channel. Unit VI $(20 \mathrm{~cm}$ in thickness) is a fluvial deposit composed of layers of sand and silt. Unit VII is composed of a lower dark loam and an upper dark sandy loam. Unit VIII is a poorly sorted sandy clay containing a variety of rounded to angular mudstone gravels and pumice clasts. The thickness of Unit VIII varies across the site. $\mathrm{T}_{3}-3$, situated adjacent to the $\mathrm{T}_{4}$ riser, measures approximately $90 \mathrm{~cm}$ thick. However, at $\mathrm{T}_{3}-2$ closest to the Paleolithic component, it measures approximately $50 \mathrm{~cm}$ thick, while $\mathrm{T}_{3}-1$, which is south of the cultural material, measures approximately $10 \mathrm{~cm}$ thick. Unit IX includes

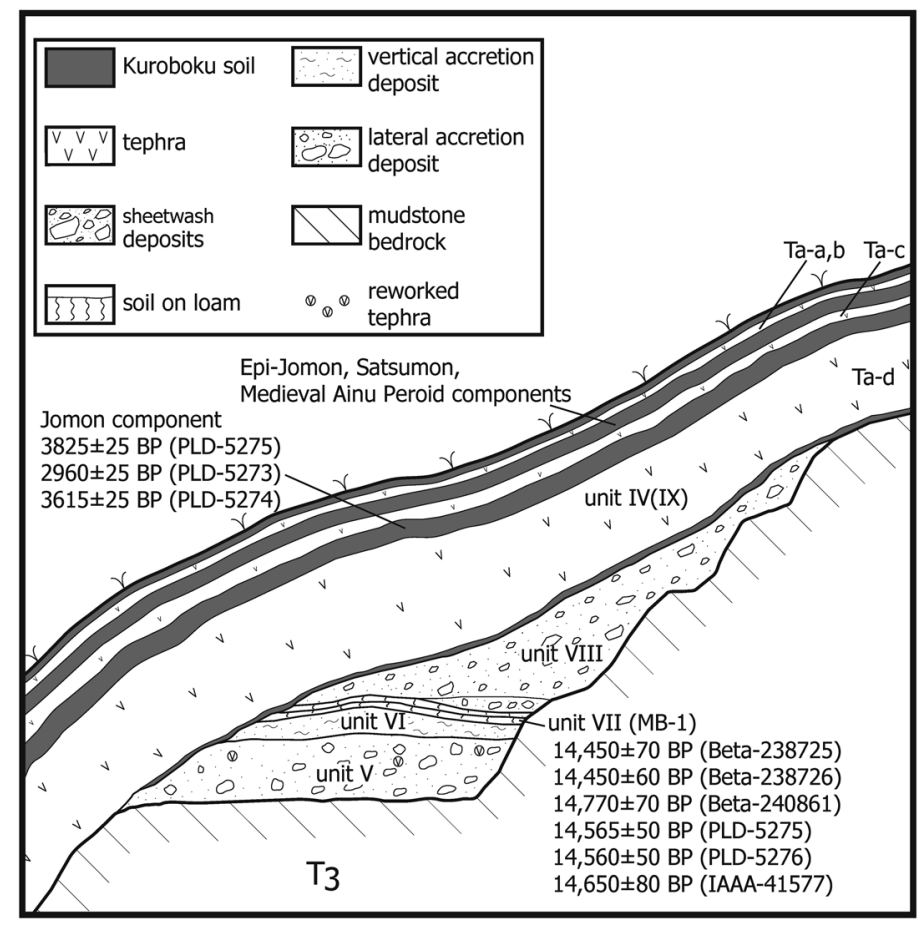

Fig. 3 Site stratigraphy at the Kamihoronai-Moi 
the buried Kuroboku soil, the Ta-d $(80-120 \mathrm{~cm})$, Ta-c $(6 \mathrm{~cm})$, and Ta-b/Ta-a $(8 \mathrm{~cm})$ tephras, as well as three buried younger Kuroboku soils, from bottom to top. The late Upper Paleolithic cultural material is contained in lithostratigraphic unit VII, bracketed by Ta-d tephra $(8,000-9,000$ yrs BP). Six AMS ${ }^{14} \mathrm{C}$ ages on charcoal from a clearly defined hearth feature fall between 14,400 and $14,800 \mathrm{yrs} \mathrm{BP}$ (Atsuma Board of Education, 2006 ; Izuho and Nakazawa, 2008).

A total of 1,412 artifacts consistent of chipped stone artifacts and thermally altered stones recovered from $295 \mathrm{~m}^{2}$ of the excavation area in Unit VII. These artifacts are horizontally scattered approximately $4 \mathrm{~m}$ along easting and $7 \mathrm{~m}$ along northing, while vertical locations of artifacts are encompassed within $30 \mathrm{~cm} ; 95 \%$ of the artifacts are distributed unimodally within a $20-\mathrm{cm}$ thickness (95\% of C.I. $=65.5-65.7 \mathrm{~m}$ above sea level). One hearth identified as a burnt patch with fragmented, fire-cracked rocks is located at the southeastern margin of the lithic scatter. Because no significant erosion and disturbance were observed in the sediments of Unit VII and all artifacts were plotted by the Total Station, this site retains potential value to elucidate behavioral and physical processes that created the observed spatial pattern.

Table 1 shows the frequency of the classes of lithic artifacts and classes of raw materials. The chipped stone artifacts mostly consist of obsidian (74\%) and hard shale (24\%). Only one agate perforator was identified. Twelve pieces of sandstones retaining burnt traits were recovered from the excavated hearth $(\mathrm{H}-1)$.

As shown in Figure 4, our previous exploratory spatial analysis of hearth and burnt artifacts suggested that there is an invisible hearth

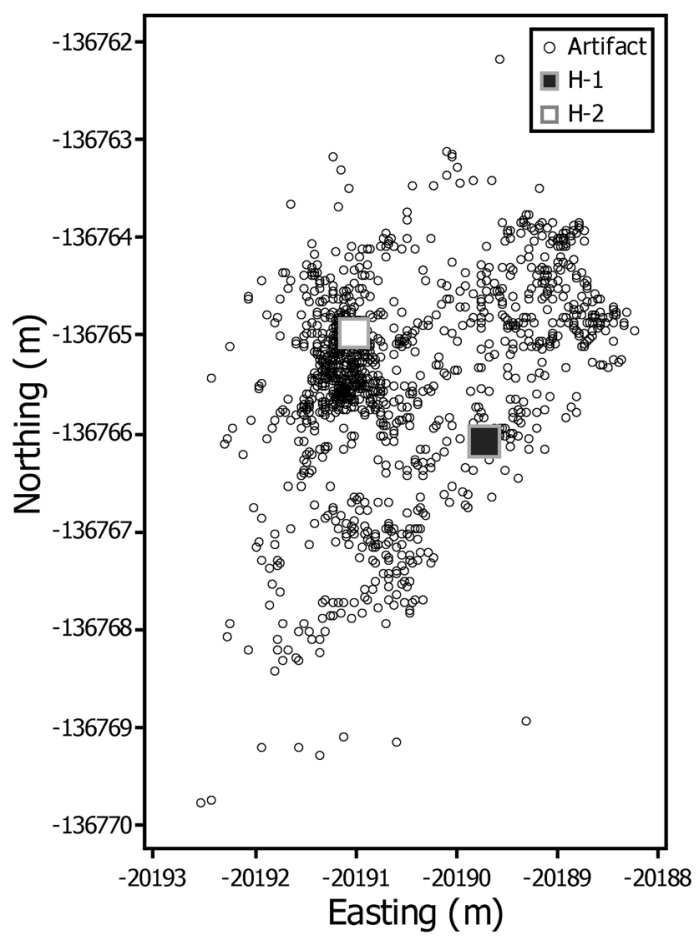

Fig. 4 Locations of the evident hearth $(\mathrm{H}-1)$ and the invisible hearth (H-2) located within the artifact distribution at the Kamihoronai-Moi

Table 1 Counts and weights of the lithics by classes of raw materials

\begin{tabular}{|c|c|c|c|c|c|c|c|c|c|c|}
\hline & \multicolumn{2}{|c|}{ Obsidian } & \multicolumn{2}{|c|}{ Hard Shale } & \multicolumn{2}{|c|}{ Agate } & \multicolumn{2}{|c|}{ Sandstone } & \multicolumn{2}{|c|}{ Total } \\
\hline & Number & Weight (g) & Number & Weight (g) & Number & Weight (g) & Number & Weight (g) & Number & Weight (g) \\
\hline Microblades & 165 & 25.19 & - & - & - & - & - & - & 165 & 25.19 \\
\hline Micro Cores & 3 & 82.19 & - & - & - & - & - & - & 3 & 82.19 \\
\hline Endscrapers & - & - & 2 & 11.67 & 一 & - & - & - & 2 & 11.67 \\
\hline Burins & - & - & 1 & 15.09 & - & - & - & - & 1 & 15.09 \\
\hline Sidescrapers & 7 & 67.58 & 1 & 0.15 & - & - & - & - & 8 & 67.73 \\
\hline Perforators & - & - & - & - & 1 & 0.22 & - & - & 1 & 0.22 \\
\hline Retouched & - & - & 1 & 4.20 & - & - & - & - & 1 & 4.20 \\
\hline Burin Spalls & - & - & 10 & 1.83 & - & - & - & - & 10 & 1.83 \\
\hline Flakes & 879 & 227.33 & 330 & 49.34 & - & - & - & - & 1209 & 276.57 \\
\hline Pebbles & - & - & - & - & 二 & - & 12 & 458.57 & 12 & 458.57 \\
\hline Total & 1052 & 402.19 & 345 & 82.28 & 1 & 0.22 & 12 & 458.57 & 1412 & 943.64 \\
\hline
\end{tabular}

"Micro Cores" designate microblade cores, and "Retouched" represents retouched flakes. "Pebbles" are all thermally altered (i.e., fire-cracked rocks). 
(called as "H-2") located $1.6 \mathrm{~m}$ northwest from the evident hearth, labeled as $\mathrm{H}^{-1}$ (Nakazawa, 2007MS, 2008 ; Nakazawa and Izuho, 2008). In addition, the levels of the evident and invisible hearths are essentially identical : the level of the evident hearth represented by burnt sediment is $65.606 \mathrm{~m}$, and the mean level of the invisible hearth represented by the mean of the elevation of burnt microblades is $65.602 \mathrm{~m}$. The nearly identical vertical locations of the two hearths suggest that we cannot separate a distinctive occupational surface, on which a particular hearth was constructed. This suggests two possible explanations regarding relationships between the depositional rate $(d)$ and the frequency of occupation $(F)$ operated on the study site. The first explanation is that the depositional rate $(d)$ was slow to separate a single occupational episode in which a hearth was constructed and used. The second one is that the frequency of occupation $(F)$ was high enough to prevent the accumulation of a distinctive amount of sedimentation (i.e., a sterile layer), which in turn mixed temporally distinctive occupational episodes. A comprehensive clarification of these two explanations will be discussed in the latter part of the paper.

\section{Hypotheses of human occupations}

In order to understand the temporal relationship of the two hearths, we pose the question as to what kinds of behavioral processes created two hearths that are closely located on an identical level in Lithostratigraphic Unit VII (Atsuma Board of Education, 2006). Two mutually exclusive processes of hearth use that can create the observed spatial arrangement of the hearths are proposed.

Process A : Two hearths functioned simultaneously on a single occupational surface.

Process B : Two hearths functioned discontinuously on the surface by multiple occupations, in seasonal and annual cycles of foraging (cf. Binford, 1980, 1982).

Isolating the plausible temporal relationship of the two hearths between these two processes is a methodological issue requiring an evaluation of the relationships among depositional processes, site integrity, and occupational intensity. We attempt to differentiate these two processes on the study site of KamihoronaiMoi through an examination of the trampling effect. We assess site occupational intensity through the effect of trampling on the vertical displacement of artifacts (e.g., Villa and Courtin, 1983 ; Gifford-Gonzalez et al., 1985 ; Nielsen, 1991 ; McBrearty et al., 1998).

\section{An assessment of spatial integrity and occupational intensity by vertical dis- placement of artifacts}

While trampling is regarded as a kind of "occupational disturbance" (Villa and Courtin, 1983 : p. 272), the timing and degree of the trampling in relation to the formation of artifact scatter will vary depending on the degree of occupational intensity. Considering that both the duration of occupation (D) and the frequency of occupations (F) affect the degree of trampling, we provide hypotheses regarding the relationship between the frequency of occupations and trampling to evaluate the two possible processes in relation to hearth use (i.e., Process A and B). If occupants utilized the hearths simultaneously during their occupation (Process A), the artifact scatter that resulted from their activities would be subject to occasional trampling, causing the vertical displacement of artifacts, but the degree of displacement would be less than that incurred in reoccupation. In contrast, if a group of huntergatherers visited the site multiple times (Process B), the artifact scatter left by a previous occupation has some chance of being disturbed by trampling. The chance of trampling also will be expected to increase as new occupants stay longer. We test these expectations through an investigation into the degree of vertical displacement of chipped stone artifacts.

Patterns in vertical distributions of artifacts relative to both hearths are not different (the elevation of the invisible hearth $[65.602 \mathrm{~m}]$ is represented by the mean of the burnt chipped stone artifacts). Because of no difference in elevations of the two hearths, in Figure 5, we only present the vertical locations of all pieceplotted artifacts $(\mathrm{N}=1314)$ relative to the level of the evident hearth $(\mathrm{H}-1)$, which are regarded as occupation level (cf. Surovell et al., 2005). Most of the artifacts distribute within $30 \mathrm{~cm}$ 


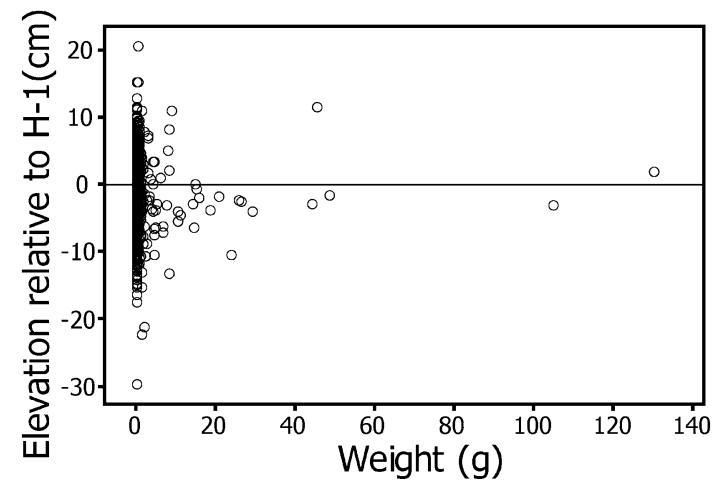

Fig. 5 Vertical distributions of artifacts relative to the location of the evident hearth $(\mathrm{H}-1)$ plotted against artifact weight $(\mathrm{g})$

Elimination of an outlier (Elevation $=64.847 \mathrm{~m})$ results in $\mathrm{N}=1314$.

range around the level of hearths (15 above and $17 \mathrm{~cm}$ below the hearth). Because all artifacts are not necessarily deposited simultaneously, we use vertical distribution of refitted artifacts to assess degree of vertical displacement. Although artifacts can be fallen apart during the period of deposition due to natural decay, refitted specimens are highly likely discarded as the moment of site occupation (Villa and Courtin, 1983). Because some of the refitted chipped stone artifacts from the study site consist of more than 3 specimens, we consider median of vertical locations of a refitted specimens as an proxy of original level, from which artifacts were displaced by postdepositional disturbances. Figure 6 plots the medians of the vertical locations in each pair of the refitted artifacts $(\mathrm{N}=$ 39) relative to the location of the evident hearth $(\mathrm{H}-1)$. They distribute between 6.4 and -11.3 $\mathrm{cm}$ around the level of the evident hearth. The median of medians among all refitted artifacts is $0.4 \mathrm{~cm}$ above the level of the hearth, suggesting that the refitted items tightly distribute around the occupation level. This indicates that some downward and upward migrations of artifacts occurred, although the extent of vertical displacement was not large enough to displace the majority of artifacts away from the occupational surface. The effect of human trampling on the downward migration of artifacts, if any, could not have been intensive.

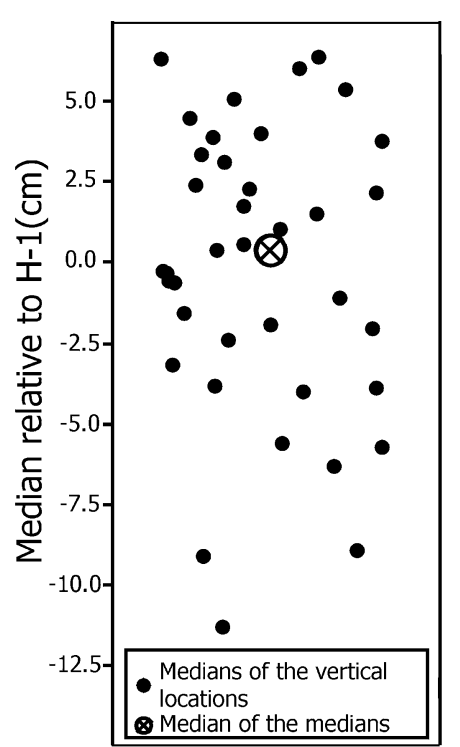

Fig. 6 Medians of the vertical location among the paired refitted artifacts $(\mathrm{N}=39)$ (represented by black dots), and the median of all the medians (represented by cross mark)

This conclusion is consistent with the analytical statement that the degree of horizontal displacement of artifacts was minimal (Nakazawa, 2008). Relative to the hypotheses proposed above, the small extent in the vertical displacement of the artifacts further implies that human occupations relative to hearth use was likely to be by Process A, rather than by Process B. A low degree of trampling supports the statement that the occupational surface, represented by hearths and associated artifacts, provides a reliable unit of analysis for studying intrasite human activities.

\section{Intrasite human activities around the two hearths}

The spatial distributions of burnt chipped stone artifacts (i.e., obsidian, hard shale), and fire-cracked rocks (FCR) in and around the two hearths are displayed in Figure 7. The burnt obsidian artifacts are mainly scattered across west of $\mathrm{H}^{-1}$ (evident hearth), particularly around the $\mathrm{H}-2$ (invisible hearth), while the burnt shale artifacts and FCR are concentrated around the $\mathrm{H}-1$. This difference in visual observation is quantitatively investigated by artifact northing 


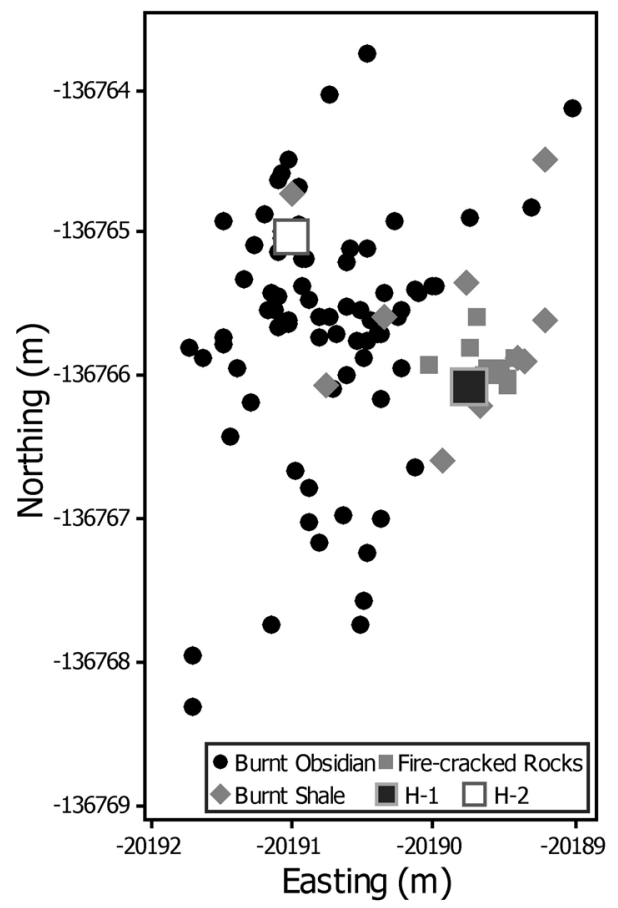

Fig. 7 Horizontal distributions of thermally altered items (burnt obsidian, burnt shale, and firecracked rocks) around the evident $(\mathrm{H}-1)$ and invisible hearths $(\mathrm{H}-2)$

and easting. Figure 8 shows the 95\% confidence intervals around the means for easting and northing, compared to among three classes of burnt materials (i.e., obsidian, FCR, and hard shale). The 95\% confidence intervals of northing (Fig. 8-a) among the three materials are overlapped, while those of easting (Fig. 8-b) are different between obsidian and the other raw materials (Tukey's multiple comparison; obsidian $\angle \mathrm{FCR}=$ hard shale, family error rate $=$ 0.05). The result of the comparison of locations suggests that burnt obsidian artifacts are spatially close to the invisible hearth $(\mathrm{H}-2)$, while burnt shale and FCR are related to the evident hearth $(\mathrm{H}-1)$. This spatial pattern will signify that burnt obsidian artifacts were created in the invisible hearth, while the burnt shale and FCR were made in the fire of the evident hearth $(\mathrm{H}-1)$. The spatial overlap of both burnt and non-burnt artifacts around the two hearths (Fig. 9) suggests that two alternative behavioral processes can create a spatial overlap.

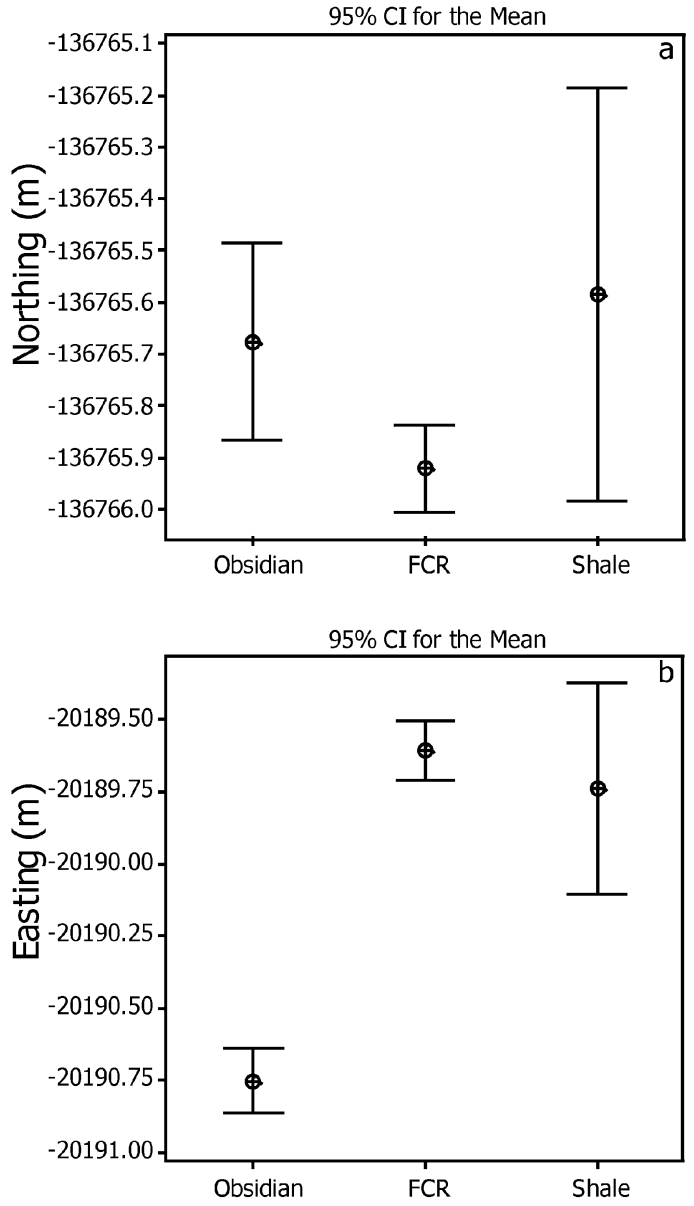

Fig. 8 95\% confidence intervals around the spatial means of northing (a) and easting (b), among obsidian, fire-cracked rocks (FCR), and hard shale

The first process is that burnt items were made by spontaneous dropping of artifacts during core and tool reductions, as well as by tool abandonment. Second is the process that the hearth was built on a previously left superficial artifact scatter, that in turn created the burnt artifacts within the artifact scatter. If a fire was built on an existing lithic scatter, more burnt hard shale is expected to be distributed around the invisible hearth $(\mathrm{H}-2)$, while more burnt obsidian will be distributed around the evident hearth $(\mathrm{H}-1)$. The observed spatial relationship (burnt shale and burnt obsidian are differentially distributed in and around the two hearths) suggests that the second expectation is un- 


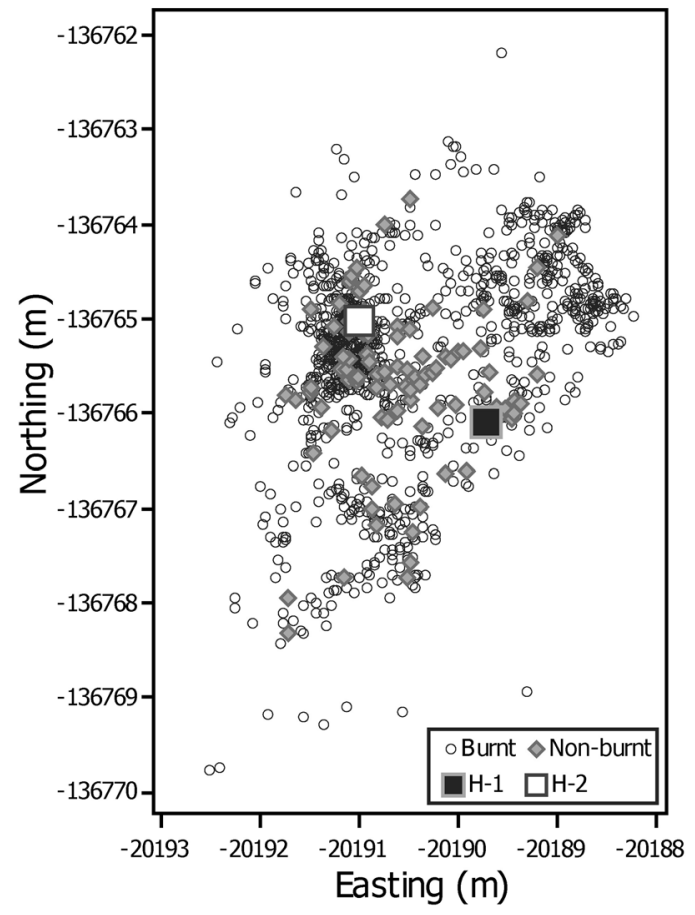

Fig. 9 Horizontal distribution of burnt and non-burnt artifacts in and around the evident hearth ( $\mathrm{H}-1)$ and the invisible hearth $(\mathrm{H}-2)$

likely. Thus, we support the first process that the occupants utilized fires on both hearths, at least during a single occupation. This implication again supports Process A which designates simultaneous function of the two hearths on a single occupational surface. In addition, it is also probable that the duration of fire use in the two hearths was short. This allowed occupants to perform activities irrelevant to fire use that in turn accumulated non-burnt artifacts overlapped with hearths and associated burnt artifacts.

\section{Discussion and conclusions}

The results of our spatial analysis of artifact distributions relative to the hearths suggest that the two hearths were functioning together on a single occupational surface. The distance of the two hearths measures only $1.6 \mathrm{~m}$, implying that the activity areas centered on the two hearths likely overlapped. This tightly arranged activity space implies that the two hearths were presumably maintained by a single group of occupants and the number of occupants was small. In addition, the spatially differentiated association of raw material types suggested by the distribution of burnt artifacts imply that functional activities performed between the two hearth-centered areas were notably different: Activities with $\mathrm{H}^{-1}$ could have involved the reduction of the hard shale tools (i.e., sidescrapers, endscraper, burin, retouched flakes), and use of the agate perforator, as well as heating the sandstone cobbles, whereas $\mathrm{H}-2$ would have a more sustained reduction of obsidian (e.g., detachments of microblades, shaping preforms of wedge-shaped microblade cores) than that of hard shale. While all materials used for the chipped stone artifacts were not locally procured (Atsuma Board of Education, 2006 ; Nakazawa et al., 2007), the distinctive consumptions of lithic materials are spatially pronounced. These observations clearly reveal that the site's occupants organized activities spatially in different ways. Our inference on the functional difference between the two hearth-centered areas also implies that the division of labor among a group of occupants was expressed in the microspace around the hearths (see Binford, 1998; Vaquero and Pastó, 2001). Moreover, the difference in tool components between obsidian and hard shale suggests that the activities performed around $\mathrm{H}^{-1}$ was preparation of skin hiding and tool maintenance, while those conducted around $\mathrm{H}-2$ were more skewed towards manufacturing microblades provided for the edges of composite tools. While our data are not sufficient to specify how different the tool classes were spatially utilized between the two hearths, or whether the inferred division of labor was sex or age-based, some degree of intrasite cooperative work was expressed in microspace use. Given the perception that division of labor played a critical role to give modern humans an evolutionary advantage in surviving Eurasia (Kuhn and Stiner, 2006), the observed spatial organization indicates that late Upper Paleolithic hunter-gatherers in northeastern Asia had maintained division of labor as well. Moreover, the organization of microspace was also in accordance with the manner of how activities were performed, which could have been linked to aspects of their foraging 
schedule, such as plans of how long they stayed and how much their transported lithic materials were reduced (Nakazawa et al., 2007).

Regarding the model of site formation processes and palimpsest accumulations (see Fig. 2 ), the number of occupants $(N)$, the site occupation duration $(D)$, and the frequency of occupations $(F)$ were all small in the Kamihoronai-Moi site, and therefore occupational intensity was regarded as low. The depositional rate $(d)$ at the study site and that of the Late Glacial in Hokkaido are currently unknown. However, in the lower part of Unit VII, in which the study assemblage is deposited, there was probably an accumulation that occurred during the period after the deposition of the En-a tephra and prior to the onset of the Younger Dryas Event, dated between 16,000 and 13,000 yrs BP. Although future research into depositional rate is required to make this statement valid, we expect that the depositional rate of the eolian loam that sealed the Upper Paleolithic occupational surface was low. Given our model of palimpsests, the low intensity of occupation and low depositional rate indicate that the chance of having a palimpsest accumulation was 'median' at the study site. Regardless of the median chance of having palimpsest accumulations, the low occupational intensity signifies that the location of Kamihoronai-Moi was only briefly occupied. In future research, we need to evaluate our model of site formation processes by conducting inter-site and interregional comparisons. Nevertheless, ephemeral use of the site occupational surface indicates that the late Upper Paleolithic hunter-gatherers used this particular location of the KamihoronaiMoi site as a transitory camp. While spatial organization of Upper Paleolithic hunter-gatherers could have varied depending on biogeographic variability in regions of Eurasia, the present research provides a valuable example of how modern humans organized micro-space in relation to hearths under the condition of a short occupation.

\section{Acknowledgements}

We thank Tetsuya Inui, Tomonori Nara, Tetsuya Ono, and the Atsuma Board of Education (Hokkaido) for permitting us to study the Paleo- lithic locality of Kamihoronai-Moi site. We also thank Elizabeth Stewart (University of New Mexico) and an anonymous reviewer of The Quaternary Research for their comments and editorial help that improved the manuscript.

\section{References}

Akazawa, T. (1980) Fishing adaptation of prehistoric hunter-gatherer at the Nittano Site, Japan. Journal of Archaeological Science, 7, 325-344.

Atsuma Board of Education (2006) Kamihoronai-Moi site (1). 234 p, Atsuma Board of Education, Atsuma Town. (J)

Audouze, F. and Enloe, J.G. (1997) High resolution archaeology at Verberie : limits and interpretations. World Archaeology, 29, 195-207.

Bailey, G.N. (2007) Time perspective, palimpsests and archaeology of time. Journal of Anthropological Archaeology, 26, 198-223.

Binford, L.R. (1980) Willow smoke and dogs' tails : Hunter-gatherer settlement systems and archaeological site formation. American Antiquity, 45, 420.

Binford, L.R. (1982) The archaeology of place. Journal of Anthropological Archaeology, 1, 5-31.

Binford, L.R. (1998) Hearth and home: The spatial analysis of ethnographically documented rock shelter occupations as a template for distinguishing between human and hominid use of sheltered space. XIII U.I.S.P.P. Congress Proceedings-Forli, 8-14 September 1996, 229-239.

Binford, L.R. and Sabloff, J.A. (1982) Paradigms, systematics, and archaeology. Journal of Anthropological Research, 38, 137-153.

Enloe, J.G. (2006) Geological processes and site structure : assessing integrity at a late Paleolithic openair site in northern France. Geoarchaeology : An International Journal, 21, 523-540.

Ferring, C.R. (1986) Rate of fluvial sedimentation : Implications for archaeological variability. Geoarchaeology : An International Journal, 1, 259-274.

Gamble, C.S. and Boismier, W.A. (1991) Ethnoarchaeological approaches to mobile campsites: Huntergatherer and pastoralist case studies. $420 \mathrm{p}$, International monographs in Prehistory. Ann Arbor.

Gifford-Gonzalez, D.P., Damrosch, D.B., Damrosch, D. R., Pryor, J. and Thunen, R.L. (1985) The third dimension in site structure : An experiment in trampling and vertical dispersal. American Antiquity, 50, 803-818.

Hietala, H.L. (1984) Intrasite spatial analysis in archaeology. 292 p, Cambridge University Press.

Huckell, B.B. (1996) The archaic prehistory of the North American Southwest. Journal of World Prehistory, 10, 305-373.

Izuho, M. and Nakazawa, Y. (2008) Natural formation processes at the Paleolithic locality of the Kamihoronai-Moi site, Hokkaido. Sato, H. (ed.) Papers for 
symposium, "What can be gained from archaeological sites? : Geoarchaeology" : 16-31, Japan Association for Quaternary Research. (J)

Jochim, M.A. (1991) Archaeology as long-term ethnography. American Anthropologist, 93, 308-321.

Kent, S. (1987) Method and theory for activity area research : An ethnoarchaeological approach. 643 p, Columbia University Press.

Kroll, E.M. and Price, T.D. (1991) The interpretation of archaeological patterning. 315 p, Plenum Press.

Kuhn, S.L. and Stiner, M.C. (2006) What's a mother to do?: The division of labor among Neanderthals and modern humans in Eurasia. Current Anthropology, 47, 953-980.

Lyman, R.L. and O'Brien, M. J. (1999) Americanist stratigraphic excavation and the measurement of culture change. Journal of Archaeological Method and Theory, 6, 55-108.

McBrearty, S., Bishop, L., Plummer, T., Dewar, R. and Conard, N. (1998) Tools underfoot: Human trampling as an agent of lithic artifact edge modification. American Antiquity, 63, 108-129.

Nakazawa, Y. (2007MS) Hearth-centered spatial organization : A comparative approach to the study of Palimpsests in Late Upper Paleolithic Sites in Hokkaido (Japan) and Cantabria (Spain). Unpublished PhD dissertation, University of New Mexico, Albuquerque, $483 \mathrm{p}$.

Nakazawa, Y. (2008) Occupational history at the Paleolithic locality of the Kamihoronai-Moi site, Hokkaido (Japan). Izuho, M., Akai, F. and Takase, K. (eds.) Ronshu Oshorokko II : 63-82, Oshorokko Kenkyukai. (J)

Nakazawa, Y. and Izuho, M. (2008) Cultural formation processes at the Paleolithic locality of the Kamihoronai-Moi site, Hokkaido. Sato, H. (ed.) Papers for symposium, "What can be gained from archaeological sites? : Geoarchaeology" : 32-40, Japan Association for Quaternary Research. (J)

Nakazawa, Y., Izuho, M. and Akai, F. (2007) The Late Glacial microblade assemblage from the Kamihoronai-Moi site in Hokkaido, northern Japan : A newly discovered Yubetsu Site. Current Research in the Pleistocene, 24, 37-40.
Nielsen, A.E. (1991) Trampling the archaeological record : an experimental study. American Antiquity, 56, 483-503.

Schiffer, M.B. (1976) Behavioral archaeology. 222 p, Academic Press.

Stein, J.K. (2001) Archaeological sediments in cultural environments. Stein, J.K. and Farrand, W.R. (eds.) Sediments in archaeological context : 1-28, University of Utah Press.

Straus, L.G. (1979) Caves : a paleoanthropological resource. World Archaeology, 10, 331-339.

Straus, L.G. (1987) Upper Paleolithic ibex hunting in SW Europe. Journal of Archaeological Science, 14, 163-178.

Straus, L.G. and Clark, G. (1986) La Riera Cave : Stone age Hunter-gatherer adaptations in northern Spain. 499p, Anthropological Research Papers, 36, Arizona State University.

Surovell, T.A., Waguenspack, N.M., Mayer, J.H., Kornfeld, M. and Frison, G.C. (2005) Shallow site archaeology : artifact dispersal, stratigraphy, and radiocarbon dating at the Barger Gulch Locality B Folsom site, Middle Park, Colorado. Geoarchaeology : An International Journal, 20, 627-649.

Vaquero, M. and Pastó, I. (2001) The definition of spatial units in Middle Paleolithic sites: The hearthrelated assemblages. Journal of Archaeological Science, 28, 1209-1220.

Villa, P. and Courtin, J. (1983) The interpretation of stratified sites : A view from underground. Journal of Archaeological Science, 10, 267-281.

Wandsnider, L. (1996) Describing and comparing archaeological spatial structures. Journal of Archaeological Method and Theory, 3, 319-384.

Waters, M.R. (1992) Principles of geoarchaeology : A north American perspective. 398 p, University of Arizona Press.

Wood, W.R. and Johnson, D.L. (1978) A survey of disturbance processes in archaeological site formation. Schiffer, M.B. (ed.) Advances in archaeological method and theory, $1: 315-381$, Academic Press.

(J) in Japanese. 


\title{
二つの炉址 : 北海道勇払郡厚真町上幌内モイ遺跡 における遺跡形成過程と空間組織
}

\author{
中沢 祐一 $* 1$ - 出穂 雅実 $* 2$, a 赤井 文人 $* 3$
}

\begin{abstract}
〔要旨〕
先史狩猟採集民の遺跡内での人間活動に関する推論を 確立するため, 北海道厚真町上幌内モイ上部旧石器遺跡 (14,400 14,800 yrs BP) の研究を行った. はじめに, パ リンプセスト（複数の行動エピソードが空間的に重複す ることによって生じた考古学的記録) が生じる確率を予 測することを目的とした, 占拠地点への居住強度・居住 集団の規模・堆積率を変数とする形式モデルを提示し た. 遺跡の層序, 堆積物, 年代, 遺物分布, 石器組成を のべた上で, 存在が推定された不可視的な炉 $(\mathrm{H}-2)$ と発 掘時に確認された炉 $(\mathrm{H}-1)$ のあいだの垂直的位置に違 いがないことについて, 堆積率と居住強度の関係から説 明を加えた。次に, 二つの炉 (炉址 : $\mathrm{H}-1$ と, 不可視的な 炉址: H-2) の利用についての仮説 : 同時利用 (プロセス A) と断続利用 (プロセス B) を提示し，それぞれについ

た. 垂直分布と二つの炉を中心とする被熱遺物の平面分 布の定量的検討から，狩猟採集集団が二つの炉を同時に 利用したこと (プロセス $\mathrm{A}$ )，そして居住強度 (居住期間 と居住頻度) は低いとみなされることが示された。ささら に, 二つの炉の周りに扔いて石器石材 (黒曜石・ “硬質頁 岩”・砂岩) の消費形態には相異があることから, それぞ れの炉に結びついた分業が想起された。 分析結果を形式 モデルに利用し，パリンプセストの生じる確率を評価す ると，上幌内モイ遺跡がパリンプセストである可能性は 中程度であったといえる. しかし分析結果そのあのが示 す居住強度の低さは, 当遺跡がごく短期間利用されたこ とを示唆している. 本研究は, 上部旧石器狩猟採集民の 短期居住開地遺跡の場の使い方にみられる行動的多様性 を理解するうえで，貴重な事例之評価できる.
\end{abstract} て踏みつけが生じた場合の遺物分布パターンを予測し

キーワード : 炉, 遺跡内活動, パリンプセスト, 上部旧石器, 北海道

\footnotetext{
*1 Department of Anthropology, MSC01-1040, Anthropology, University of New Mexico. Albuquerque, NM 871310001, USA.

*2 札幌市埋蔵文化財センター $\mathbf{T} 064-0922$ 札幌市中央区南 22 条西 13 丁目（現住所 : 首都大学東京都市教養学部 $\boldsymbol{\mathbf { T }} 192-$ 0397 八王子市南大沢 1-1).

*3 北海道大学大学院文学研究科 $\overline{\mathbf{T}} 060-0810$ 札幌市中央区北 7 条西 10 丁目.

*a Corresponding author : izuhom@tmu.ac.jp
} 